\title{
COMPARATIVE ANALYSIS OF ADMINISTRATIVE AND LEGAL PRINCIPLES OF TAX ADMINISTRATION IN THE CONDITIONS OF DECENTRALIZATION IN EUROPE AND UKRAINE
}

\author{
Leonid Mogilevskyi ${ }^{1}$ \\ Secretariat of the Academic Council, \\ Kharkiv National University of Internal Affairs, Ukraine \\ Eugene Barash ${ }^{2}$ \\ Institute of Criminal Execution Service, Ukraine \\ Andrew Sakovskyi ${ }^{3}$
}

Educational and Scientific Institute № 2 of the National Academy of Internal Affairs of Ukraine, Ukraine

\begin{abstract}
The aim of the article is a comparative analysis of the administrative and legal regulation of taxadministration in European countries and in Ukraine and the definition of ways to improve domestic legislation in this field on this basis. The subject of the study is the administrative and legal principles of tax administration in the conditions of decentralization of state power. Methodology. The study is based on a comparison of the foreign experience of legal regulation and collection of local taxes by using the example of European states with the current state of the process of introducing tax decentralization in Ukraine. Due to the use of this amount of general scientific and specialscientific methods and methods of scientific knowledge, the content of the administrative and legal foundations of tax administration, as well as legal phenomena such as tax decentralization, were characterized and defined. The conclusions that we made helped us to determine the specifics of their administrative-legal regulation in some countries of Europe and in Ukraine. The results of the conducted comparative legal study made it possible to prove the direct impact of tax decentralization on the mechanism of tax administration and the systematic organization of tax authorities. These processes have a predominantly positive impact on macroeconomic processes, they broaden the rights and opportunities of local authorities regarding the use of funds by local governments, forecasting and approving regional budgets, and managing taxes and fees. Practical impact. The administration of taxes in the conditions of decentralization in Europe can be characterized by a high level of efficiency and functionality of the work of the territorial tax-control bodies. This experience is really necessary for Ukraine, where the activities of local self-government in some areas are limited by the central apparatus. Value/originality. A comparative legal study of world experience in the legal regulation of tax administration under conditions of financial decentralization, which consists of a whole complex of individual normative structures and procedures, gives us a better understanding of the prospects for the development of national administrative legislation in this area.
\end{abstract}

Key words: administration of taxes, decentralization, administrative and legal principles.

JEL Classification: M11, E42

\section{Topicality}

The effective and high-quality taxation system, which supports the economic situation of the country and the filling of the budget, is an important factor in the functioning of any modern state with a market economy. The process of collecting taxes is a rather complex phenomenon, which has its own normativelegal consolidation, as well as the corresponding implementation principles. The administrative and legal provisions occupy the prominent place among them. On the bases of these principles, the system of regulation and direct collection of mandatory, legally determined payments is based. At the same time, administration of taxes serves today as the purpose of many reform processes, along with other fields of legal activity of society in Ukraine. The financial

\footnotetext{
Corresponding author:

${ }^{1}$ Kharkiv National University of Internal Affairs.

${ }^{2}$ Institute of Criminal Execution Service.

${ }^{3}$ Educational and Scientific Institute № 2 of the National Academy of Internal Affairs of Ukraine
} 
decentralization is one of them. This aspect is primarily connected with the integration of our state into the European community, which requires a number of changes in the legal, economic, political, and other fields. That is why the problem of tax administration in the conditions of financial decentralization, which consists of a complex of separate normative structures and procedures, is a priority area of scientific and practical research. However, considering that the mentioned issue is the novelty of the modern economic and legal sphere of Ukraine, we consider it necessary to conduct a comparative analysis of the latter, taking into account the foreign experience of European countries, in order to determine the perspectives for the development of tax administration and the place in this process of administrative and legal principles.

\section{The level of the development}

The analysis of scientific literature has shown that many scholars have raised issues, which are connected with the functioning of the tax system, in their researches. Particularly, the analysis of the peculiarities of national taxation was carried out by such scientists as: Daudova V.H., Barannyk L.B., Heiets V.M., Andrushchenko V.L., Kyrylenko O.P., Kravchenko V.I., Lunina I.O., Sokolovska N.V., and others. Proskura K.P., Zakharchenko V.Yu., Ivanova Yu.B., Krysovatyi A.I., and others studied practical and theoretical aspects of tax administration. In its turn, various taxation issues in other countries were highlighted in the works of such foreign scholars as: Devero M., Wilson D., Tabellini G., Diamond D., White M., Perrotti R. et al. Despite the existence of a large number of doctrinal views on different aspects of tax administration, a comparative analysis of the administrative and legal principles of this phenomenon in the conditions of decentralization in Ukraine and in the territory of foreign states was not carried out.

The aim of the article is a comparative analysis of the administrative and legal principles of tax administration in the conditions of decentralization in Europe and Ukraine.

\section{Statement of the basic material}

The scientific development of this problem we should begin with the definition of the content of such terms as "administrative and legal principles of tax administration" and "decentralization". It should be noted that such term as "administrative and legal principles of tax administration" comes from the classical category of legal principles, that is, from the key principles of legal reality. In this case, the principles and bases should be considered as synonyms, since the meaning of both words is identical. Regarding the definition of the latter, there are several views in the scientific environment. For example, according to Prokopenko V.I., legal principles are the main subjective rights and responsibilities (Prokopenko, 1969; Strachuk, 2012). A broader and more comprehensible understanding of legal principles is proposed in the works of O.F. Skakun, P.M. Rabinovich, K.E. Livantseva, Yu.A.Vedernikova, and others. According to their concept, the principles of law are the guiding ideas, which are objectively inherent bases of the law, and the indisputable requirements (positive obligations). They are put to the participants of social relations in order to harmonize the combination of individual, group, and public interests and they determine the content and direction of legal regulation, they reflect the most important patterns of socio-economic formation (Strachuk, 2012; Skakun, 2009; Rabinovych, 1995; Vedyernikov, Hrekul 2005). If we will use this theoretical concept regarding the definition of administrative and legal principles, separately from the sphere of tax administration, then its content is most closely matched with the scientific view of Panova N.S. The scientists point out that the administrative and legal principles are a set of administrative and legal norms, which define the main values, tasks, forms, and methods of development of normative and regulatory activities of executive bodies (Zabroda, 2013; Panova, 2008). The second part of the concept of "administrative and legal principles of tax administration" also has its own content load.

It is logical to assume that administration is a cumulative process, which is aimed at achieving a certain goal. In our case, it is the collection of legally established, mandatory taxes and fees. Confirmation of this definition can be found in the scientific concepts of many scholars. For example, Khavkina O.G. considers administration of taxes as a management activity of state authorities, which is associated with the organization of the tax process and which is built on state legislative and regulatory acts (Kravtsova, 2017; Khavkina, 2005). Melnyk V.M. provides a more detailed definition in his works. In his view, tax administration is an activity of executive authorities, it has managerial nature, and it is based on state legislative and regulatory acts, and it uses socially determined and accepted rules. Besides, administration, as a direction of activity, consists of accounting, mass-explanatory and advisory work, forecast analytical work and control and analytical work (Kravtsova, 2017; Melnyk, 2006). The view of Barabanova V.V. is rather interesting also. She understands under the administration of taxes not only the administrative activity of the public-law nature of the tax authorities regarding the formation of state revenues but also business entities in order to implement the provisions of the tax code (Khomutenko, Lutsenko, Khomutenko, 2015; Barabanova). However, despite a large number of doctrinal definitions, the legislative, legal justification of tax administration takes the main place. According to the current Tax Code, the latter is a set of decisions and procedures of the controlling 
bodies and the actions of their officials that determine the institutional structure of tax and customs relations, organize the identification, registration of taxpayers and payers of the single payment and objects of taxation, provide service to taxpayers, organization and control over the payment of taxes, fees, payments in accordance with the procedure established by law (Podatkovyy kodeks Ukrayiny, 2011).

Thus, summarizing all the mentioned, the administrative and legal principles of tax administration can be defined as the initial provisions of normative and managerial activities of the authorized bodies in the area of implementation of relevant decisions and procedures, which are aimed at the organization and regulation of relations related to the collection of official payments, fees, and taxes. Their expression can be traced in the provisions of the legislative and bylaws acts, which establish the scope of application, powers and functions of the relevant state bodies involved in the organization of the taxation process in Ukraine. It is also expedient to consider separately the meaning of the term "decentralization", considering the complexity of the phenomenon that is described. According to the explanatory dictionary, decentralization is a management system, in which a part of the functions of central government passes into local self-government bodies. In other words, the extension of rights of local governing bodies is carried out (Busel, 2005). According to Borislavska A.N., decentralization is a quite complex concept, which can be revealed through its influence on: administrative-territorial structure of the state, the system of bodies of public administration, distribution between them of functions, powers, and financial resources. In fact, it is such a way of defining and demarcating tasks and functions, in which most of them pass from the level of central bodies to a lower level and become their own tasks and powers of the bodies of the lowest level (Boryslavska, Zaverukha, Zakharchenko, 2012). However, in our case, we are talking about decentralization of the taxation system. It forms a large array of individual institutes that are organically combined with classical phenomena. It is necessary to present the scientific view of Ostrovetskyi V.I. on this issue. The scientist points out that decentralization means the transfer of responsibility for increasing the expenditure and revenue parts of the budget to the local level. A decentralized system should ensure the level, quality, and content of public services and it should be coordinated with the preferences of voters, providing incentives for the efficiency of such services (Ostrovetsky, (2016). Therefore, taking into account the presented scientific views, it can be concluded that $\operatorname{tax}$ decentralization is a redistribution of the rights and functions of the central government, according to which the territorial authorities are given more powers in the field of taxation and regulation of financial and budgetary relations.
So, by characterizing and defining the content of the administrative and legal principles of tax administration and the phenomenon of tax decentralization, we can analyse the current state of these categories on the territory of Ukraine and European states.

It should be noted that tax decentralization is a novelty in our country today because it is connected with the provision of local authorities with extended rights in the field of local budgets formation. The corresponding changes in the legislation began only in 2014 in order to build such internal financial relations. By this time, local budgets entirely depended on the general state treasury. The following legal documents became the regulatory basis for tax decentralization: the Law of Ukraine "On Amendments to the Tax Code of Ukraine and Certain Legislative Acts of Ukraine on Tax Reform" on 28.12.2014 (Pro vnesennya zmin do Podatkovoho kodeksu Ukrayiny, 2015); The Law of Ukraine "On Amendments to the Budget Code of Ukraine on the Reform of the Intergovernmental Fiscal Relations" on 28.12.2014 (Pro vnesennya zmin do Byudzhetnoho kodeksu Ukrayiny, 2015); The Law of Ukraine "On Amendments to the Budget Code of Ukraine regarding the Peculiarities of the Implementation of Budgets of the United Territorial Communities" dated November 26, 2015 (Pro vnesennya zmin do Byudzhetnoho kodeksu Ukrayiny, 2016); The Law of Ukraine "On Amendments to the Tax Code of Ukraine and Certain Legislative Acts of Ukraine regarding the Balance of Budget Revenues in 2016" of 24.12.2015, etc. (Pro vnesennya zmin do Podatkovoho kodeksu Ukrayiny, 2016). These normative legal acts clearly divided the national and local taxes and fees.

So, in the structure of the local obligatory, legislatively established payments according to changes are included: - property tax;

- single tax.

- parking fee for vehicles;

- tourist tax (Podatkovyy kodeks Ukrayiny, 2011).

As we can see, the legislator has substantially limited the number of taxes and fees that form local budgets of territorial units. It should be noted that before carrying out the corresponding reforms and adoption of the new Tax Code of Ukraine, sixteen separate taxes and fees have been carried into the number of local taxes (On Local Taxes and Duties: Decree of May 20, 1993). At first glance, such changes seem very negative because the local budgets were actually "cut" sources. However, tax decentralization has changed not only the list of taxes and fees, which go exclusively to local budgets but also redistributed nationwide mandatory payments. Thus, the filling of the state treasury and budgets of urban significance is carried out in a percentage ratio. For example, according to the Budget Code of Ukraine, 60 percent of the personal income tax is attributed to territorial revenues; 10 percent of corporate income tax, etc. (Byudzhetnyy kodeks Ukrayiny). 
In general, according to Daudova H.V. introduction of budget decentralization has fundamentally changed the quality of financial support of local budgets. Changes to the budget and tax legislation have defined new approaches to the formation of the revenue side of local budgets, which has resulted in the increase of the own resources of the territorial communities.

The growth of financial resources is connected with the:

- with the introduction of new taxes and fees charged to local budgets;

- with the redistribution of revenues from state and local budgets (the state fee for the issuance of passports and fees for the provision of other administrative services); -with the optimization of thesystem ofintergovernmental transfers (Daudova, 2015).

Besides, according to the analysis of the Centre for the preparation of reforms, tax decentralization can also be characterized by a number of other features.

Of course, the most positive of them is the acquisition of the financial independence by the local budgets. Therefore, cities, big and small villages can plan their development under any conditions, having already got their own funds for this. Under such conditions, a part of the funds coming to local budgets in the form of subventions and subsidies is not so urgent because there is already a "financial pillow". Another positive factor is the fact that local authorities, in a context of tax decentralization, can, through a simplified procedure, provide local guarantees and borrowings from international financial institutions (Herus). It should be noted that the introduction of tax decentralization undoubtedly affects the mechanism of tax administration. In accordance with the provisions of the Tax Code of Ukraine, this mechanism is implemented by the corresponding executive body. So, such body for today is the State Fiscal Service of Ukraine. Its activities are directed and coordinated by the Cabinet of Ministers of Ukraine through the Minister of Finance, which implements state tax policy, state policy in the field of state customs, state policy on administering a single contribution to compulsory state social insurance, state policy in the field of fighting offenses during application tax, customs legislation, as well as legislation on payment of single payment (Pro derzhavnu fiskalnu sluzhbu).

The influence of tax decentralization on the administration mechanism, of course, in no way left a reflection on the system organization of the tax authorities, which represent a hierarchical structure. However, with the expansion of financial and budgetary autonomy of local self-government, there appeared an urgent issue of assessing the effectiveness of administering compulsory payments and fees. The concept "efficiency" in this case should be defined as the ratio of the received result and the expenditures that were used to achieve it (Litvinova, 2014). In our opinion, in the context of the administration of local taxes, effectiveness demonstrates the significance and efficiency of tax decentralization, as well as the feasibility of implementing certain normative or practical actions whose purpose is to fill the local treasury. Viktorchuk M.V. also expresses the following opinion in his dissertation research. The latter outlines the criteria for determining the effectiveness of administering local taxes and fees, which include:

- indicator of the appeal of the effectiveness of administering local taxes and fee;

- the level of achievement of goals and fulfilment of tasks of tax decentralization;

- the level of collection of local taxes and fees;

- the level of adaptation of the system of taxation of local taxes and charges for changes in the environment (particularly, to changes in legislation);

- the ratio of the number of monetary claims in disputes between tax authorities and taxpayers, which are considered by the courts in favour of tax authorities;

- decrease in debt on taxes;

- increase in a share of payers who appraise work of tax bodies positively according to sociological researches; - increase in a share of the payers, who have a possibility of access with the help of communication channels and the Internet to the personified information about the condition of calculations with the budget, etc. (Viktorchuk, 2016).

Besides, in our opinion, an effective factor in ensuring the effective implementation of the tax administration mechanism under the conditions of tax decentralization at the local level is the competent system of informing the population of the corresponding territory. Today's lack of knowledge about the content of legal phenomena that exist in our state and peculiarities of their functioning is a major problem for Ukrainian society. This negative factor also has its manifestation in the field of taxation. Lack of proper awareness leads to the wrong perception of legal reality by citizens and, as a consequence, it leads to the commission of offenses. Increase in level of informing local population by tax authorities will become a functional preventive factor, which will increase the efficiency of administration of taxes and fees on places in the conditions of decentralization.

So, having analysed features of the taxation at the local level, we have defined that the presented mechanism has ways of improvement in the conditions of tax decentralization because tax decentralization is at a development stage today. Considering this fact, it is necessary to analyse the foreign provision of administrative and legal bases of administration of taxes in the conditions of decentralization on the example of the European countries. This approach will allow us to learn the most relevant and positive points of view of the effectiveness of taxation, and, besides, it will help to abandon the negative, inhibiting mechanism of the administration of factors. 
In Europe, decentralization, as an economic and legal phenomenon, is not a novelty, unlike in Ukraine. Particularly, the first signs of decentralization processes have already been observed in the 11 th-12th centuries in England. Thus, Richard I (1157-1199), when he needed money for the financing of the Crusades, began to use actively the fast and efficient ways of replenishing the state treasury - the sale to the city of the charter, which guaranteed them certain privileges. Particularly, the cities, with the consent of the Crown, were granted the right to self-government, legal proceedings, consolidation of fortifications, and the creation of armed units for the maintenance of law and order. But the most important thing is that their tax status has changed. After the charter was donated, certain administrativeterritorial entities in the property and legal aspects acquired such force and significance that the king could not withhold anymore from them any taxes, except for the collection from the city (Hrechakivskyy, Kabash, 2009; Smyt, 1992). Later, the theory of decentralization of power in all spheres of social life and the acquisition of a wide range of rights for local self-government developed under the influence of the reform processes in Europe. Some concepts of decentralization have been reflected in modern international legal documents, such as the European Charter of Local Self-Government (Hrechakivskyy, Kabash, 2009).

At t0he modern historical stage, the peculiarities of the influence of decentralization on the taxation mechanism can be analysed using the example of many European states. It should be noted that the approach to the organization of local government in Europe differs from the Ukrainian one, which significantly affects the tax system and the mechanism of its administration. For example, in Poland, for many years, a concept has been built in which the development of regions can be possible only on condition of stable financial income. It is this factor that allows planning of the development of social infrastructure and introducing economic incentives for business development in the long term. In Poland, such a stable income is local taxes. Direct local taxes are: inheritance tax and gift, agricultural tax, forest taxes, real estate, transport tax and dog owners' tax. Besides, there are so-called fees as: market (in fact, payment for a place on the market), local, and administrative fees. Also, at the territorial level, there is a tax that is paid in the form of a "tax card", which in fact corresponds to our single tax. In a certain percentage ratio, the share of the personal income tax (PIT) and the profit of enterprises are counted to the local budget of territorial units (Rosolyak, Martsiyas, 2016). We should note that the administration of taxes in Poland can be characterized by high level of control over financial expenditures from the budgets of local self-government bodies. Particularly, the network of regional accounts chambers is very close to local budgets, and it is easy to see abuse. This body is a rough, non-emotional financial audit and control. In turn, the Ministry of Finance of Poland does not have access to many registries; it does not participate in the collection and payment of local taxes

The register of real estate for payment of taxes is led by the head of the gmina (an administrative-territorial unit in Poland), who is interested in ensuring that the register is as clear as possible, because the revenues to the budget, which is administered by the gmina, depend on it. It is at the level of the gmina, where the control is provided over the charge and payment of tax. And the verification of these processes is carried out by regional audit chambers (Rosolyak, Martsiyas, 2016).

The example of tax administration in the context of decentralization in Romania is quite informative and interesting. Tax decentralization in the territory of this country has greatly expanded the rights and opportunities of local authorities regarding the use of funds by local self-government bodies, forecasting and approval of regional budgets, management of taxes and fees. The main state bodies that support the decentralization reform are the Ministry of the Interior and administrative reform, which are involved in the special programs of financing the European Union. The legislation of Romania specifies sources of financing local budgets, for example: state transfers, the share of national taxes, grants and subsidies; the property of state authorities, local taxes, fees, and borrowings. The regulatory base also regulates an order of formation, acceptance, and execution of local budgets and an order of financing of utilities and the organizations of the municipal sector. Some of the latest amendments to the Local Finance Act provide additional rights to introduce local taxes and fees to the local governments. Besides, according to the provisions of Romanian law, the main principles of tax decentralization and tax administration are:

- a uniform income level;

- proportionality;

- completeness;

- the local character of the financial system, etc. (Detsentralizatsiya vlady, 2015).

In Spain, there is a special form of tax decentralization. In the territory of this country, this process is connected with democratization. Therefore, the Spanish Constitution of 1978 fixes the concept of asymmetry. Its essence lies in the fact that decentralization is divided into several modes - special, exclusive, and general. It should be noted that the exclusive regime applies only to the Basque Country and Navarre, while the general regime extends to the other 15 autonomous territories. The main difference between these regimes is that the special regime regions have powers to collect taxes at the regional level, while in the general-mode regions such a possibility is significantly restricted. Under the special regime, most of the taxes are transferred to the autonomous government, together with the 
responsibility for tax administration; and that means, consequently, that this government can establish an appropriate level and base of taxation. All main types of taxes - from income, corporate taxes, to wealth, inheritance and the transfer of wealth - are completely under the administration of regional authorities. In regions with a special regime, citizens do not pay any part of these taxes to the central government. The reform in 1997 increased the powers of the tax authorities of the named regions, and the value-added tax was also transferred to the regional authorities, however, without any powers to establish its rates or to define the base of taxation. But, with the aim of compensation for services that were provided by the central government to the region, the regional government pays to the central power a certain sum, which look like a transfer or grant (Boryslavska, Zaverukha, Zakharchenko, 2012).

\section{Conclusions}

By conducting a scientific analysis of the all mentioned information, we have come to a number of corresponding conclusions.

1. Tax decentralization in Ukraine is a positive phenomenon in general. It allows significantly expanding the capacity of local self-government bodies in the area of the formation of a territorial basis, which, in turn, allows regions to develop independently and to use their own money for their own needs, regardless of the power centre. Instead, tax decentralization is also characterized by some negative features. Particularly, its introduction is a positive factor for the developed, economically and politically stable regions. On the territory of other administrative-territorial units, where such stability does not exist, the crisis events may deepen and gradually increase its effect.

2. Decentralization does not have a qualitative effect on the mechanism of tax administration, which is carried out by special tax bodies, the system of which is hierarchical and centralized. This aspect needs to be changed, according to the model of the Republic of Poland, where special control agencies are close to local budgets of territorial units

3. Positive and interesting in the long term for Ukraine is Spain's experience in tax administration in the context of decentralization. On the territory of this European state, the regulation of fees and charges is fully ensured by the local authorities. This is primarily due to the tax policy of Spain. Most taxes and fees remain at the territorial level. In compensation for a high level of autonomy, the local government pays to the central government some amount, which is determined by the law.

4. In general, the administration of taxes in the conditions of decentralization in the territory of Europe can be characterized by the high level of efficiency and functionality of operation of territorial tax supervisory authorities. Besides, the European local government has a wide range of the rights which give a certain "freedom" in all questions, which are connected with coordination of the taxation and work of the subjects involved in this sphere. This experience is rather necessary for Ukraine where activity of local government in some spheres is limited by the central office.

\section{References:}

Prokopenko, V. I. (1969). Osnovnyye printsipy trudovogo prava [Main principles of labor law]. Kyiv, 12 (In Russian)

Strachuk, O. V. (2012). Shchodo ponyattya pryntsypiv prava [Concerning the concept of the principles of law]. Chasopys Kyyivskoho universytetu prava. Journal of the Kyiv University of Law. 40-43. (In Ukrainian)

Skakun, O. F. (2009). Teoriya derzhavy i prava : pidruchnyk [Theory of state and law: a textbook]. Kharkiv: Konsyl. 221. (In Ukrainian).

Rabinovych, P. M. (1995). Osnovy zahalnoyi teoriyi prava i derzhavy : navchalnyy posibnyk [The bases of the general theory of law and state: a manual]. Kyiv: ISDO. 93 (In Ukrainian)

Vedyernikov, Yu. A., Hrekul V. S. (2005). Teoriya derzhavy i prava : navch. Posib. [Theory of state and law: teach. manual]. Kyiv: Tsentr navch. 1-ry. 79. (in Ukrainian)

Zabroda, D. H. (2013). Administratyvno-pravovi zasady: sutnist ta zmist katehoriyi: sutnist ta zmist katehoriyi [Administrative and legal principles: the nature and content of the category: the nature and content of the category]. Administratyvne pravo i protses - Administrative law and process. 45-51. (in Ukrainian)

Panova, N. S. (2008). Administratyvno-pravovi zasady rozvytku derzhavnoho upravlinnya v suchasniy Ukrayini : avtoref. dys. kand. yuryd. nauk : spets. 12.00 .07 «Administratyvne pravo i protses; finansove pravo; informatsiyne pravo» [Administrative and legal principles of development of public administration in modern Ukraine: author's abstract. dis Cand. lawyer Sciences: special 12.00.07 «Administrative law and process; finance law; information law»]. 19. (In Ukrainian)

Kravtsova, T. M. (2017). Administruvannya podatkiv yak systemoutvoryuyuchyy pravovyy instrument opodatkuvannya v Ukrayini [Administration of Taxes as a System-Generating Legal Instrument of Taxation in Ukraine]. Pryvatne ta publichne pravo - Private and public law. №1. 64-67. (in Ukrainian)

Khavkina, O. (2005). Administruvannya podatkiv ta napryamy upravlinskoyi diyalnosti [Administration of taxes and directions of management activity]. Opodatkuvannya v noviy systemi ekonomichnykh vidnosyn Ukrayiny: Materialy mizhvuz. Student. Konf-Taxation in the New System of Economic Relations of Ukraine: Intermediate 
Materials. Student. Conf. Irpin: Nats. akad. derzhavnoyi podatkovoyi sluzhby Ukrayiny. - Irpin: National acad. the State Tax Service of Ukraine. 236. (in Ukrainian)

Melnyk, V. (2006). Opodatkuvannya : naukove obgruntuvannya ta orhanizatsiya protsesu : monohrafiya [Taxation: scientific substantiation and process organization: monograph]. K.: «Kompyuterpres $\gg .277$. (In Ukrainian)

Khomutenko, V. P., Lutsenko, I. S., Khomutenko, A.V. (2015). Administruvannya podatkiv, zboriv, platezhiv [Administration of taxes, fees, payments]. O.: «Atlant».314. (In Ukrainian)

Barabanova, V. V. Suchasnyy stan administruvannya podatkiv [The current state of tax administration]. Materialy XI Mizhnarodnoyi naukovo-praktychnoyi konferentsiyi "Dynamika evolyutsiyi lyudskoho intelektu, etykoestetychnoho spryynyattya svitu ta khudozhnoyi tvorchosti" [Materials of the XI International Scientific and Practical Conference "Dynamics of evolution of human intelligence, ethical and aesthetic perception of the world and artistic creativity"]. Retrieved from: http://icpua.com/ru/node/1059

Podatkovyy kodeks Ukrayiny: zakon vid 02.12.2010 \#2755-VI (2011). [Tax Code of Ukraine: Law dated 02.12.2010 №2755 - VI]. - №13. - art.112.

Busel, V. T. (2005). Velykyy tlumachnyy slovnyk suchasnoyi ukrayinskoyi movy [Great explanatory dictionary of modern Ukrainian language]. K.; Irpin': VTF «Perun». 1728. (in Ukrainian)

Boryslavska, O., Zaverukha, I., Zakharchenko, E. (2012). Detsentralizatsiya publichnoyi vlady : dosvid yevropeyskykh krayin ta perspektyvy Ukrayiny [Decentralization of public authority: experience of European countries and prospects of Ukraine]. Shveytsarsko-ukrayinskyy proekt «Pidtrymka detsentralizatsiyi v Ukrayini Swiss-Ukrainian project "Supporting of the decentralization in Ukraine DESPRO». K. : TOV «Sofiya». 128. (in Ukrainian)

Ostrovetsky, V. I. (2016). Podatkova polityka Ukrayiny v umovakh detsentralizatsiyi [Tax policy of Ukraine in the conditions of decentralization]. Visnyk ekonomichnoyi nauky Ukrayiny - Bulletin of Economic Science of Ukraine, №2, 140-143.(in Ukrainian)

Pro vnesennya zmin do Podatkovoho kodeksu Ukrayiny ta deyakykh zakonodavchykh aktiv Ukrayiny shchodo podatkovoyi reformy: zakon vid 28.12.2014 \#71(2015) - VIII [On Amendments to the Tax Code of Ukraine and Certain Legislative Acts of Ukraine on Tax Reform: Law dated December 28, 2014 №71 - VIII]. Ofitsiynyy visnyk Ukrayiny - Official Bulletin of Ukraine, №3, art.46. (In Ukrainian)

Pro vnesennya zmin do Byudzhetnoho kodeksu Ukrayiny shchodo reformy mizhbyudzhetnykh vidnosyn : zakon vid 28.12.2014 \#79 (2015) - VIII [On Amendments to the Budget Code of Ukraine on the Reform of the Intergovernmental Fiscal Relations: Law from December 28, 2014 №79 - VII]. Vidomosti Verkhovnoyi Rady Ukrayiny -News of the Verkhovna Rada of Ukraine. №12. Art. 76. (In Ukrainian)

Pro vnesennya zmin do Byudzhetnoho kodeksu Ukrayiny shchodo osoblyvostey formuvannya ta vykonannya byudzhetiv obyednanykh terytorialnykh hromad : zakon vid 26.11.2015 \#837 (2016) - VII [On Amendments to the Budget Code of Ukraine regarding the Peculiarities of the Formation and Implementation of the Budgets of the Unified Territorial Communities: the Law dated November 26, 2015, No. 837 -VII], № 1, art.11. (In Ukrainian)

Pro vnesennya zmin do Podatkovoho kodeksu Ukrayiny ta deyakykh zakonodavchykh aktiv Ukrayiny shchodo zabezpechennya zbalansovanosti byudzhetnykh nadkhodzhen u 2016 rotsi : zakon vid 24.12.2015 \#909 - VII (2016) [On Amendments to the Tax Code of Ukraine and certain legislative acts of Ukraine on ensuring the balance of budget revenues in 2016: Law dated December 24, 2015 No. 909 - VII]. Vidomosti Verkhovnoyi Rady Ukrayiny -News of the Verkhovna Rada of Ukraine, №5, art.47. (In Ukrainian)

On Local Taxes and Duties: Decree of May 20, 1993 No. 56-93 [Pro mistsevi podatky i zbory: dekret vid 20.05.1993 \#56-93]. Vidomosti Verkhovnoyi Rady Ukrayiny -News of the Verkhovna Rada of Ukraine, №30, art.336.v. (In Ukrainian)

Byudzhetnyy kodeks Ukrayiny: zakon vid 08.07.2010 \#2456 - VI [Budget Code of Ukraine: Law dated 08.07.2010 № 2456 - VI]. Vidomosti Verkhovnoyi Rady Ukrayiny -News of the Verkhovna Rada of Ukraine, №50, №50-51, art.572. (In Ukrainian)

Daudova, H. V. (2015). Byudzhetoutvoryuyuchi podatky mistsevykh byudzhetiv u konteksti byudzhetnoyi detsentralizatsiyi [Budget-making local budget taxes in the context of fiscal decentralization]. Teoriya ta praktyka derzhavnoho upravlinnya - Theory and practice of public administration, №5, 3, 150-155. (In Ukrainian)

Herus, A. Finansova detsentralizatsiya, abo shcho robyty $\mathrm{z}$ hroshyma [Financial decentralization, or what to do with money]. Detsentralizatsiya. Decentralization. Retrieved from: http://decentralization.gov.ua/news/2045.

Pro derzhavnu fiskalnu sluzhbu: postanova vid 21.05.2014 \#236 [About the state fiscal service: the resolution dated May 21, 2014 №236]. Ofitsiynyy visnyk Ukrayiny - Official Bulletin of Ukraine, №55, art.1507. (In Ukrainian)

Litvinova, V. O. (2014). Ekonomichna efektyvnist : sutnist ta formy [Economic efficiency: essence and forms]. Visnyk Berdyanskoho universytetu menedzhmentu i biznesu - Bulletin of the Berdyansk University of Management and Business, №2(26). 43-45. (In Ukrainian)

Viktorchuk, M. V. (2016). Administratyvno-pravove rehulyuvannya mistsevykh podatkiv i zbriv v Ukrayini v umovakh yevrointehratsiyi : dysertatsiya [Administrative and legal regulation of local taxes and weapons in Ukraine in conditions of European integration: dissertation]. Kharkiv, 219. (In Ukrainian)

Hrechakivskyy, S. D., Kabash, O. R. (2009). Teoretychnyy lohos fiskalnoyi detsentralizatsiyi [The theoretical logos of fiscal decentralization]. Rehionalna ekonomika - Regional economy, №2, 133-143. (In Ukrainian) 
Smyt, A. (1992). Yssledovanye o pryrode y prychynakh bahatstva narodov [Study about the nature and causes of the wealth of nations]. M:Nauka, 572. (In Russian)

Rosolyak, O., Martsiyas, I. (2016). Finansova detsentralizatsiya : dosvid Polshchi ta realiyi Ukrayiny [Financial decentralization: Poland's experience and realities of Ukraine]. Aktualni problemy pravoznavstva - Actual problems of law, №2, 66-70. (In Ukrainian)

Detsentralizatsiya vlady na osnovi krashchykh inozemnyk praktyk ta ukrayinskykh zakonodavchykh initsiatyv (2015). [Decentralization of power based on best foreign practices and Ukrainian legislative initiatives]. Materialy informatsiynoho seminaru - Materials of the informative seminar. Retrieved from: http://www.uiip.org.ua/ wp-content/uploads/2015/05/робочi-матеріали-Аля-учасників-заходів.pdf. (In Ukrainian) 